\title{
Educational paper
}

\section{Syndromic forms of primary immunodeficiency}

\author{
Rogier Kersseboom • Alice Brooks • Corry Weemaes
}

Received: 19 November 2010 / Accepted: 11 January 2011 / Published online: 22 February 2011

(C) The Author(s) 2011. This article is published with open access at Springerlink.com

\begin{abstract}
The syndromic primary immunodeficiencies are disorders in which not only the immune system but also other organ systems are affected. Other features most commonly involve the ectodermal, skeletal, nervous, and gastrointestinal systems. Key in identifying syndromic immunodeficiencies is the awareness that increased susceptibility to infections or immune dysregulation in a patient known to have other symptoms or special features may hint at an underlying genetic syndrome. Because the extraimmune clinical features can be highly variable, it is more difficult establishing the correct diagnosis. Nevertheless, correct diagnosis at an early age is important because of the possible treatment options. Therefore, diagnostic workup is best performed in a center with extensive expertise in this field, having immunologists and clinical geneticists, as well as adequate support from a specialized laboratory at hand. This paper provides the general pediatrician with the main clinical features that are crucial for the recognition of these syndromes.
\end{abstract}

Keywords Syndromic immunodeficiency · Primary immunodeficiency · Genetics - DNA repair disorders · 22q11 deletion syndrome

\section{Abbreviations \\ WAS Wiskott-Aldrich syndrome \\ $\mathrm{CHH} \quad$ Cartilage-hair hypoplasia}

R. Kersseboom $(\bowtie) \cdot$ A. Brooks

Department of Clinical Genetics,

Room Ee2014, Erasmus MC Rotterdam,

P.O. Box 2040, NL-3000 CA Rotterdam, The Netherlands

e-mail: r.kersseboom@erasmusmc.nl

\section{Weemaes}

Department of Pediatrics,

Radboud University Nijmegen Medical Centre,

Nijmegen, The Netherlands
NBS
A-T
Nijmegen breakage syndrome
ICF syndrome
Ataxia telangiectasia
HIES
DS
and facial dysmorphisms syndrome
Down syndrome
syndromic PID Syndromic primary immunodeficiencies
SCID
BMT
Severe combined immunodeficiency
Bone marrow transplantation
HSCT
Hematopoietic stem cell transplantation

\section{Introduction}

The syndromic primary immunodeficiencies (syndromic PID) are disorders in which not only the immune system but also other organ systems are affected. In contrast to other primary immunodeficiencies, more often features other than the immune-defect are the presenting symptoms. Nevertheless, patients with syndromic PID may present with recurrent infections as well. In many malformation and/or mental retardation syndromes, increased rates of infections are assumed to result mainly from anatomical problems, failing physiological mechanisms, and institutionalization. In contrast, syndromic PID have an intrinsic abnormality of the immune system that increases susceptibility to infections. Within the IUIS classification system, syndromic PID are mainly found in the category of "other well defined immunodeficiency syndromes" but are present in many other categories as well [54]. We advocate using the name "syndromic PID" because it lays more emphasis on the extraimmune phenotype, which, in fact, can be prominent.

Syndromic PID can be caused by single gene disorders, metabolic aberrations, and chromosomal abnormalities, and 
for some, the genetic basis has not yet been unraveled. In general, the genetic defects in syndromic PID impact on important cellular processes thereby affecting multiple cell lines and organ systems. In DNA repair disorders (ataxia telangiectasia, Bloom syndrome, and Nijmegen breakage syndrome), all cells are affected resulting in severe growth retardation, neurological disease in some, increased susceptibility to malignancy, and predisposition to infections. Immunodeficiency likely results from aberrant DNA repair in lymphocytes during the somatic recombination events, such as $\mathrm{V}(\mathrm{D}) \mathrm{J}$ recombination (the process of antigen receptor diversification by combining different gene segments) and class switch recombination (the process of immunoglobulin isotype switching) that are necessary to generate the enormous range of specificities of antigen receptors [79]. In other syndromic PID such as hyper-IgE syndrome, Wiskott-Aldrich syndrome or hypohidrotic ectodermal dysplasia with immune-deficiency, signaling molecules are affected that transmit signals from a variety of receptors in different cell types thereby resulting in features in several organ systems.

This paper provides the general pediatrician with the main clinical features that are crucial for the recognition of syndromic PID [49]. In addition, a short overview of current diagnostic and therapeutic options is given. In Table 1, an overview is provided that helps making a differential diagnosis starting from several lead symptoms such as, e.g., facial dysmorphisms, growth failure, and skin problems. For the general diagnostic approach, readers are referred to the first paper in this educational series (de Vries and Driessen).

\section{Ataxia telangiectasia}

Ataxia telangiectasia (A-T; OMIM 208900) is an autosomal recessive disorder caused by mutations in the $A T M$-gene, a protein kinase that is involved in DNA repair [66]. Clinical features are progressive cerebellar ataxia, oculocutaneous telangiectasias, immunodeficiency, and increased susceptibility to malignancies, particularly lymphomas and leukemias [70]. Ataxia develops shortly after learning to walk and begins as truncal ataxia but, within several years, involves peripheral coordination as well. Neurological disturbances also include extrapyramidal symptoms (Fig. 1a-1). From about 10 years on, most children become wheelchair-bound for the remainder of their lives. The hallmark feature of A-T "oculocutaneous telangiectasias" usually appears at about 4 to 6 years of age (Fig. 1a-2).

Most patients suffer from recurrent respiratory infections. Systemic bacterial, severe viral, and opportunistic infections are uncommon in A-T. In patients with classical A-T, both humoral and cellular immunity are disturbed with $\operatorname{IgA}, \operatorname{IgG} 2$, and $\mathrm{IgG} 4$ deficiency as most common manifestations [55]. However, $10 \%$ of A-T patients present with decreased serum $\operatorname{IgG}$ and $\operatorname{IgA}$ with normal or raised IgM levels, resulting in more severe infections, thus showing a phenotype reminiscent of hyper-IgM syndrome [52]. Antibody responses to tetanus and diphtheria toxoid show protective levels, but the majority has a specific polysaccharide antibody deficiency. $\mathrm{T}$ cells have been found to be decreased in a considerable fraction of patients, with a specific reduction in the numbers of naïve CD4+ cells $(C D 4+C D 45 R A+$ cells) and naïve CD8+ cells (CD8+CD45RA+ cells). NK cell numbers are elevated [67].

In recent years, it was recognized that some patients present with a milder form of A-T, atypical A-T. Although affected patients had extrapyramidal symptoms (even in childhood), ataxia was less severe or even absent and patients were not wheelchair-bound and had normal immunoglobulins [73, 82]. Whereas classical A-T is characterized by loss of function, atypical A-T cases typically have some residual ATM kinase activity left.

Diagnosis of A-T can be suspected from the combination of clinical features, a slight increase in blood $\alpha$-fetoprotein in the majority of patients and from typical cytogenetic aberrations. Standard karyotyping of peripheral blood lymphocytes can be difficult because lymphocytes are less responsive to mitogenic stimuli resulting in few metaphases. When successful, a 7;14 translocation can be found in $5-15 \%$ of lymphocytes. More commonly, a radiosensitivity assay of lymphoblasts or fibroblasts is used to confirm A-T.

In all patients with classical Ataxia teleangiectasia,

teleangiectasias are absent in the first years of

life. Ataxia develops shortly after learning to walk.

\section{Nijmegen breakage syndrome}

Nijmegen breakage syndrome (NBS; OMIM 251260) is a rare autosomal recessive disorder first described in 1981 by Weemaes et al. in two brothers with microcephaly, small stature, facial dysmorphisms, and immunodeficiency [83]. NBS is more common in Eastern European and Slavic populations due to a relatively high carrier frequency. In 1998, the gene causing NBS was discovered, and it was shown that mutations in the NBS1gene resulted in loss of NBS1 and deficient DNA repair [81]. 
Table 1 Considerations on the differential diagnosis in patients presenting with:

\begin{tabular}{|c|c|c|c|c|c|}
\hline Disease & $\mathrm{T}$ cells & $\mathrm{B}$ cells & Serum Ig & Associated features & Molecular defect \\
\hline \multicolumn{6}{|l|}{ MICROCEPHALY } \\
\hline $\begin{array}{l}\text { DNA ligase IV } \\
\text { deficiency }\end{array}$ & $\downarrow$ & $\downarrow$ & $\downarrow$ & $\begin{array}{l}\text { Growth retardation, dysmorphisms, } \\
\text { radiation sensitivity }\end{array}$ & DNA ligase $I V$ \\
\hline $\begin{array}{l}\text { Cernunnos } \\
\text { deficiency }\end{array}$ & $\downarrow$ & $\downarrow$ & $\downarrow$ & $\begin{array}{l}\text { Intrauterine and postnatal growth } \\
\text { retardation, radiation sensitivity }\end{array}$ & Cernunnos \\
\hline $\begin{array}{l}\text { Nijmegen } \\
\text { breakage } \\
\text { syndrome }\end{array}$ & $\downarrow$ & $\mathrm{N} \downarrow$ & $\begin{array}{l}\text { Often IgA } \downarrow \\
\text { IgG } 2 \downarrow\end{array}$ & Bird-like face, radiation sensitivity & $N B S 1(N B N)$ \\
\hline Rad 50 deficiency & $\mathrm{N}$ & $\mathrm{N}$ & & Radiation sensitivity & RAD50 \\
\hline Bloom syndrome & $\mathrm{N}$ & $\mathrm{N}$ & reduced & $\begin{array}{l}\text { Intrauterine and postnatal growth } \\
\text { retardation, sun-sensitive erythema, } \\
\text { short stature }\end{array}$ & $\begin{array}{l}\text { recQ-like } \\
\text { helicase BLM }\end{array}$ \\
\hline $\begin{array}{l}\text { Hoyeraal-Hreidarsson } \\
\text { syndrome }\end{array}$ & $\mathrm{N} \downarrow$ & $\mathrm{N} \downarrow$ & variable & $\begin{array}{l}\text { Cerebellar hypoplasia, intrauterine } \\
\text { growth retardation, pancytopenia }\end{array}$ & $D K C 1$ \\
\hline \multicolumn{6}{|l|}{ GROWTH DEFECT } \\
\hline \multicolumn{6}{|l|}{ Dysproportional } \\
\hline Cartilage-hair hypoplasia & $\downarrow$ & $\mathrm{N}$ & $\begin{array}{r}\text { normal or } \\
\text { reduced }\end{array}$ & Short-limbed dwarfism, sparse hair & $M R M P$ \\
\hline $\begin{array}{l}\text { Schwachman-Diamond } \\
\text { syndrome } \\
\text { Proportional }\end{array}$ & $\mathrm{N}$ & $\mathrm{N}$ & normal & $\begin{array}{l}\text { Pancytopenia, exocrine pancreatic } \\
\text { insufficiency }\end{array}$ & $S B D S$ \\
\hline Bloom syndrome & $\mathrm{N}$ & $\mathrm{N}$ & reduced & $\begin{array}{l}\text { Intrauterine and postnatal growth } \\
\text { retardation, sun-sensitive erythema, } \\
\text { short stature }\end{array}$ & $\begin{array}{l}\text { recQ-like } \\
\text { helicase BLM }\end{array}$ \\
\hline $\begin{array}{l}\text { Nijmegen breakage } \\
\text { syndrome }\end{array}$ & $\downarrow$ & $\mathrm{N} \downarrow$ & $\begin{array}{l}\text { Often IgA } \downarrow \\
\operatorname{IgG} 2 \downarrow\end{array}$ & Bird-like face, radiation sensitivity & $N B S 1(N B N)$ \\
\hline Cernunnos & $\downarrow$ & $\downarrow$ & $\downarrow$ & $\begin{array}{l}\text { Intrauterine and postnatal growth } \\
\text { retardation, radiation sensitivity }\end{array}$ & Cernunnos \\
\hline \multicolumn{6}{|l|}{ FACIAL DYSMORPHISMS } \\
\hline ICF syndrome & $\mathrm{N} \downarrow$ & $\mathrm{N} \downarrow$ & Hypogammaglobulinemia & Centromeric instability, infections & DNMT3B/? \\
\hline \multicolumn{6}{|l|}{ Bird-like face } \\
\hline $\begin{array}{l}\text { Nijmegen breakage } \\
\text { syndrome }\end{array}$ & $\downarrow$ & $\mathrm{N} \downarrow$ & $\begin{array}{l}\text { Often IgA } \downarrow \\
\operatorname{IgG} 2 \downarrow\end{array}$ & Bird-like face, radiation sensitivity & $N B S 1(N B N)$ \\
\hline Cernunnos & $\downarrow$ & $\downarrow$ & $\downarrow$ & $\begin{array}{l}\text { Intrauterine and postnatal growth } \\
\text { retardation, radiation sensitivity }\end{array}$ & Cernunnos \\
\hline Ligase IV deficiency & $\downarrow$ & $\downarrow$ & $\downarrow$ & $\begin{array}{l}\text { Growth retardation, dysmorphisms, } \\
\text { radiation sensitivity }\end{array}$ & DNA ligase $I V$ \\
\hline $\begin{array}{l}\text { Down syndrome } \\
\text { (e.g. trisomy 21) }\end{array}$ & $\mathrm{N}$ & $\mathrm{N}$ & N-reduced & Dysmorphisms & $\begin{array}{l}\text { Chromosomal } \\
\text { disorder }\end{array}$ \\
\hline 22q11 Deletion & $\downarrow$ & $\mathrm{N}$ & N-reduced & $\begin{array}{l}\text { Conotruncal malformation, } \\
\text { velopharyngeal insufficiency }\end{array}$ & $\begin{array}{l}\text { Chromosomal } \\
\text { disorder }\end{array}$ \\
\hline $\begin{array}{l}\text { Hyper-IgE syndrome } \\
\text { AD }\end{array}$ & Th17 $\downarrow$ & $\mathrm{N}$ & $\operatorname{IgE} \uparrow$ & $\begin{array}{l}\text { Distinctive facial features, fractures, } \\
\text { scoliosis, retained primary dentition }\end{array}$ & STAT3 \\
\hline $\begin{array}{l}\text { Hyper-IgE syndrome } \\
\text { AR }\end{array}$ & Th17 N- $\downarrow$ & $\mathrm{N}$ & $\operatorname{IgE} \uparrow$ & $\begin{array}{l}\text { Some have distinctive facial features, } \\
\text { susceptibility to viral infections and } \\
\text { mycobacterial infections }\end{array}$ & DOCK $8, T Y K 2$ \\
\hline \multicolumn{6}{|l|}{ SKIN DISORDERS } \\
\hline Omenn syndrome & restricted & $\mathrm{N} \downarrow$ & $\begin{array}{l}\text { Decreased, } \\
\operatorname{IgE} \uparrow\end{array}$ & Erythroderma, SCID & $\begin{array}{l}\text { RAG1/2, Artemis, } \\
\text { ADA, } \\
\text { unknown. }\end{array}$ \\
\hline \multicolumn{6}{|l|}{ Atopic Dermatitis } \\
\hline $\begin{array}{l}\text { Wiskott-Aldrich } \\
\text { Syndrome }\end{array}$ & $\mathrm{N} \downarrow$ & $\mathrm{N}$ & $\begin{array}{l}\operatorname{IgM} \downarrow, \operatorname{IgA} \uparrow, \\
\operatorname{IgE} \uparrow\end{array}$ & Microthrombocytopenia & $W A S$ \\
\hline $\begin{array}{l}\text { Hyper-IgE syndrome } \\
\text { AD }\end{array}$ & Th17 $\downarrow$ & $\mathrm{N}$ & $\operatorname{IgE} \uparrow$ & $\begin{array}{l}\text { Distinctive facial features, fractures, } \\
\text { scoliosis, retained primary dentition }\end{array}$ & STAT3 \\
\hline
\end{tabular}


Table 1 (continued)

\begin{tabular}{|c|c|c|c|c|c|}
\hline Disease & $\mathrm{T}$ cells & B cells & Serum Ig & Associated features & Molecular defect \\
\hline $\begin{array}{l}\text { Hyper-IgE syndrome } \\
\text { AR }\end{array}$ & Th17 N $-\downarrow$ & $\mathrm{N}$ & $\operatorname{IgE} \uparrow$ & $\begin{array}{l}\text { Some have distinctive facial features, } \\
\text { susceptibility to viral infections and } \\
\text { mycobacterial infections }\end{array}$ & DOCK8, TYK2 \\
\hline STAT5b deficiency & $\downarrow$ & $\mathrm{N}$ & Normal & Growth hormone insensitive dwarfism & STAT5b \\
\hline $\begin{array}{l}\text { Comél-Netherton } \\
\text { syndrome }\end{array}$ & $\mathrm{N}$ & $\downarrow$ & $\begin{array}{l}\operatorname{IgE} \uparrow \operatorname{IgA} \uparrow \\
\quad \text { antibodies } \downarrow\end{array}$ & $\begin{array}{l}\text { Congenital ichthyosiform erythroderma, } \\
\text { trichorrhexis invaginata, and an atopic } \\
\text { diathesis }\end{array}$ & SPINK5 \\
\hline \multicolumn{6}{|l|}{$\begin{array}{l}\text { Anhydrotic ectodermal } \\
\text { dysplasia }\end{array}$} \\
\hline NEMO & $\mathrm{N}-\uparrow$ & & $\begin{array}{l}60 \% \text { IgG } \downarrow \text {, sometimes } \\
\text { hyper-IgM }\end{array}$ & $\begin{array}{l}\text { May have distinctive facial features, } \\
\text { conical incisors, hypohydrosis }\end{array}$ & NEMO \\
\hline $\mathrm{I} \kappa \mathrm{B} \alpha$ deficiency & Naive T cells $\uparrow$ & & $\operatorname{IgM} \uparrow \uparrow \operatorname{IgG} \downarrow$ & Conical teeth & $I \kappa B \alpha$ \\
\hline $\begin{array}{l}\mathrm{Ca}^{2+} \text { channel } \\
\text { deficiency }\end{array}$ & $\mathrm{N}$ & $\mathrm{N}-\uparrow$ & $\mathrm{N}-\uparrow$ & $\begin{array}{l}\text { Severe immunodeficiency, muscular } \\
\text { hypotonia, severely impaired T cell } \\
\text { function }\end{array}$ & STIM-1, ORAI-1 \\
\hline $\begin{array}{l}\text { Chronic mucocutaneous } \\
\text { Candidiasis } \\
\text { Hypopigmentation }\end{array}$ & $\mathrm{N}$ & $\mathrm{N}$ & Normal & Defect in Th17 cells & CARD9, Dectin-1 \\
\hline Chediak Higashi & $\mathrm{N}$ & $\mathrm{N}$ & Normal & $\begin{array}{l}\text { Low NK cells, partial albinism, } \\
\text { encephalopathy }\end{array}$ & LYST \\
\hline Griscelli Syndrome & $\mathrm{N}$ & $\mathrm{N}$ & Normal & $\begin{array}{l}\text { Partial albinism, encephalopathy } \\
\text { in some }\end{array}$ & $R A B 27 A$ \\
\hline \multicolumn{6}{|l|}{ Warts } \\
\hline WHIM & & $\downarrow$ & Hypogammaglobulinemia & & CXCR4 \\
\hline \multicolumn{6}{|l|}{ ATAXIA } \\
\hline Ataxia telangiectasia & $\downarrow$ & $\mathrm{N}-\downarrow$ & Often IgA $\downarrow$ IgG2 $\downarrow$ & $\begin{array}{l}\text { Ocular telangiectasia, radiation } \\
\text { sensitivity }\end{array}$ & ATM \\
\hline $\begin{array}{l}\text { Ataxia telangiectasia } \\
\text { like disease }\end{array}$ & $\downarrow$ & $\mathrm{N}$ & & Radiation sensitivity & MRE11 \\
\hline
\end{tabular}

Characteristic clinical features include microcephaly, growth retardation, bird-like facial features, combined immunodeficiency, and a strong predisposition for lymphoid malignancies (Fig. 1b) [32, 83]. All patients have microcephaly and short stature, their body length being below the 10 th centile in all cases. In about $75 \%$, microcephaly is already present at birth. The facial appearance is characterized by a receding forehead, prominent midface with long nose and long philtrum, receding mandible, upward slanting of palpebral fissures, epicanthic folds, large ears with dysplastic helices, and sparse hair. The distinctive facial features may not be present before the age of 3 years. Commonly clinodactyly and/or syndactyly may be found. In almost all patients, skin pigmentary changes can be observed. Although mental development was normal in 22 out of 55 patients $(40 \%)$, about 28 out of 55 patients $(50 \%)$ had borderline to mild retardation, while five out of 55 patients (10\%) were moderately mentally retarded [32]. In a minority of cases, congenital malformations are found. Predisposition to lymphoid malignancy is strong.

Patients suffer from repeated infections, most frequently recurrent airway and ENT infections followed by recurrent urinary tract infections [32]. Commonly, $\operatorname{IgG}$ and $\operatorname{IgA}$ deficiency is found and less frequently $\operatorname{IgA}$ deficiency is accompanied by IgG2 and/or IgG4 deficiency, while IgM deficiency is rare [32]. Often, the percentage of $\mathrm{T}$ cells is decreased, due to low numbers of CD4+ T cells. Especially naïve CD4+ cells (CD4+CD45RA+ cells) have been shown to be reduced. The frequency of $\mathrm{CD} 8+$ cells usually does not appear to be affected $[32,46]$. NK cells are normally present. In vitro responses of lymphocytes to mitogenic stimuli such as phytohemagglutinin (PHA) are decreased in most patients.

Diagnosis can be suspected from standard karyotyping of peripheral blood lymphocytes, revealing inversions and translocations involving chromosomes 7 and 14 in $10-50 \%$ of metaphases. Furthermore, radiosensitivity of fibroblasts or lymphocytes may be increased. 

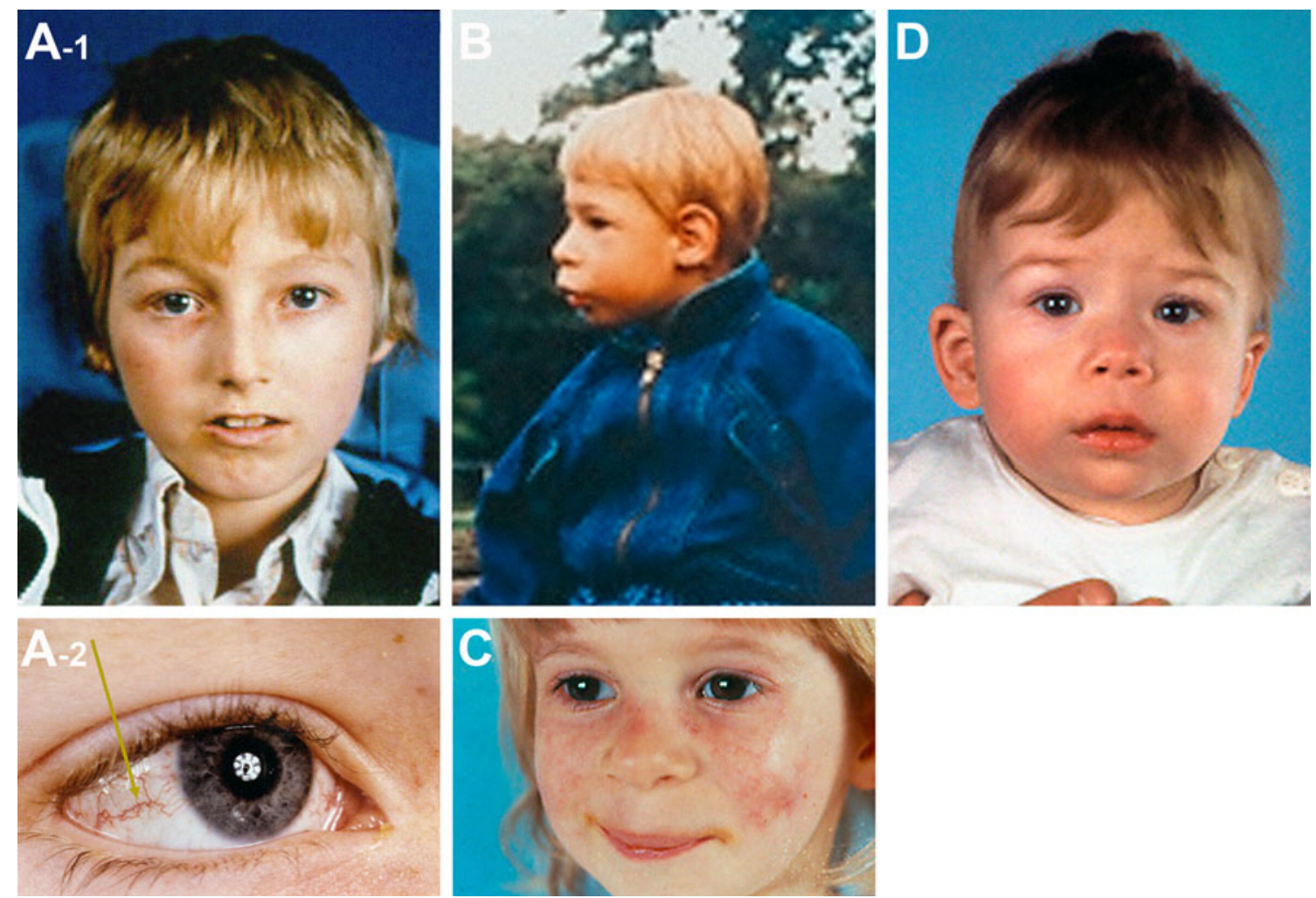

Fig. 1 Photographs highlighting several important clinical features from four classical syndromic PID, which can be diagnosed by cytogenetic studies. (a-1, a-2) Ataxia telangiectasia: note the conjunctival telangiectasias and the rather expressionless facies; (b) Nijmegen breakage syndrome: note the microcephaly, the prominent midface with long nose and long philtrum, receding mandible, large ears, and sparse hair; (c) Bloom syndrome: note the butterfly rash on the cheeks; (d) ICF syndrome: note the epicanthic folds, flat broad nasal bridge with ocular hypertelorism, and low-set ears
Of note, microcephaly and radiosensitivity have also been found in some other syndromic immunodeficiencies such as Cernunnos/XLF and Ligase IV deficiency. Patients with Cernunnos/XLF deficiency (OMIM 611291) have growth retardation, microcephaly, dysmorphic features, and urogenital malformations. Their immunodeficiency is characterized by mild-to-severe $\mathrm{B}$ and $\mathrm{T}$ cell lymphopenia, whereas NK cells are unaffected [6]. Patients with Ligase IV deficiency (OMIM 606593) are characterized by microcephaly, growth retardation, a bird-like face, pancytopenia, and may have a severe combined immunodeficiency (SCID) phenotype as well [56, 78].

Prenatal onset of growth deficiency and
microcephaly, and increased susceptibility to
infections may point at DNA repair disorders such as
Nijmegen breakage syndrome and Bloom syndrome.

\section{Bloom syndrome}

Bloom syndrome (OMIM 210900) is an autosomal recessive disorder caused by inactivating mutations in the Blmgene, a RecQ-helicase involved in DNA repair [19]. Although Bloom syndrome is very rare, it is found more frequently in Ashkenazi Jewish populations. Patients present with severe prenatal and postnatal growth retardation, microcephaly, and sun-sensitive erythematous lesions (SLE-like butterfly rash) that are mostly found on sunexposed regions of the face (Fig. 1c) [24]. In infancy, vomiting and diarrhea are common problems. Importantly, Bloom syndrome patients have a significantly increased risk for one or multiple malignancies. The tumor types and sites involved resemble that in the general population, although onset is much earlier. In the first two decades of life, predominantly, leukemia and non-Hodgkin's lymphoma are found. Later in life, epithelial cancers from the colon and upper respiratory tract occur more frequently.

Immunodeficiency is highly variable and usually not severe, although most patients experience recurrent airway 
and ENT infections. Left untreated, this can result in bronchiectasis. Immunoglobulin levels (especially $\operatorname{IgM}$ ) are decreased in most patients. T, B, and NK cells are present in normal numbers, but in vitro responses of lymphocytes to mitogens can be decreased [84].

Diagnosis can be suspected from standard karyotyping showing quadriradial configurations and increased numbers of spontaneous chromatid breaks and gaps. A very specific confirmatory cytogenetic test evaluates the number of sister chromatid exchanges per metaphase, which is highly increased in Bloom syndrome patients.

Classic cytogenetic tests such as standard
karyotyping of mitogen stimulated lymphocytes and
evaluation of the frequency of sister chromatid
exchanges can be very helpful in diagnosing Ataxia
telangiectasia, Nijmegen breakage syndrome, Bloom
syndrome and ICF syndrome.

\section{ICF syndrome}

Immunodeficiency, centromeric instability, and facial dysmorphisms syndrome (ICF-syndrome; OMIM 242860) is an autosomal recessive disease characterized by facial dysmorphisms, immunodeficiency, and branching of chromosomes 1, 9, and 16 after PHA stimulation of lymphocytes [42]. In about half of the patients, mutations in the DNMT3B-gene, a gene involved in DNA methylation, can be found [29, 30, 88]. Facial dysmorphism, including epicanthic folds, hypertelorism, flat nasal bridge, and lowset ears, are very frequent findings (Fig. 1d) [29]. Malignancies have been described infrequently [68].

Recurrent airway and ENT infections are very common, but opportunistic infections were described in several patients as well. Although hypogammaglobulinemia up to agammaglobulinemia have been shown to be present in nearly all patients, $\mathrm{B}$ and $\mathrm{T}$ cell numbers and subpopulations are generally normal.

Diagnosis can be confirmed by standard karyotyping of mitogen-stimulated lymphocytes revealing formation of multiradiate chromosomes 1,9 , and 16 .

Life expectancy is poor, especially in patients with severe infections in infancy or chronic gastrointestinal problems and failure to thrive. Allogeneic stem cell transplantation has been successfully employed although long-term results are not yet available [23].

\section{Wiskott-Aldrich syndrome}

Wiskott-Aldrich syndrome (WAS; OMIM 301000) is a rare Xlinked recessive condition that was first recognized in 1937 by Alfred Wiskott, a German pediatrician, who described a family with three boys suffering from the "classical triad" microthrombocytopenia, recurrent infections, and atopic eczema [57]. WAS is caused by mutations in the WAS-gene which is located on Xp11.22. Although only males present with the full spectrum of Wiskott-Aldrich syndrome, incidentally, females with mild microthrombocytopenia have been reported caused by skewed X-inactivation [3, 53]. WAS includes a spectrum of disorders including classical WAS, Xlinked thrombocytopenia (XLT), intermittent XLT, and Xlinked congenital neutropenia.

During the first years of life, the main health problem in classical WAS is thrombocytopenia, resulting in intermittent mucosal bleeding, bloody diarrhea, and intermittent or chronic petechiae and purpura [74]. Microthrombocytopenia is mostly congenital and lifethreatening bleeding can be precipitated by serious infections. About $80 \%$ of classical WAS patients also have mild-to-severe eczema (Fig. 2a). In addition, in classical WAS, infections are often severe with susceptibility to bacterial, viral (VZV and HSV), and even opportunistic organisms (Pneumocystis jiroveci). At least $40 \%$ of those who survive the early complications develop one or more autoimmune conditions such as autoimmune hemolytic anemia, vasculitis, neutropenia, arthritis, renal disease, and inflammatory bowel disease [16, 69, 74]. Importantly, individuals with WAS have a $13 \%$ risk of developing lymphomas especially when autoimmune disease is present [74]. Although patients with XLT do have microthrombocytopenia, eczema and immune dysfunction are mild in comparison to classical WAS.

In patients with classical WAS, both humoral and cellular immunity are disturbed with lymphocyte numbers decreasing over time, resulting in mild-to-more-severe lymphopenia [57, 76]. IgM is mostly decreased, whereas IgG remains generally within normal limits. In contrast, IgA and $\operatorname{IgE}$ can be elevated. Furthermore, serological responses to polysaccharide antigens are markedly depressed, indicative of a specific polysaccharide antibody deficiency.

Although WAS can be readily recognized on the basis of the clinical triad this constellation is present in only $25 \%$ of patients with classical WAS at diagnosis [74]. As microthrombocytopenia with increased bleeding tendency is the most common symptom of WAS, WAS should be considered in each such case. Diagnosis can be confirmed by a combination of an assay capable of detecting WASP protein and genetic testing. Differential diagnosis includes Omenn syndrome and hyper-IgE syndrome, which may also present 

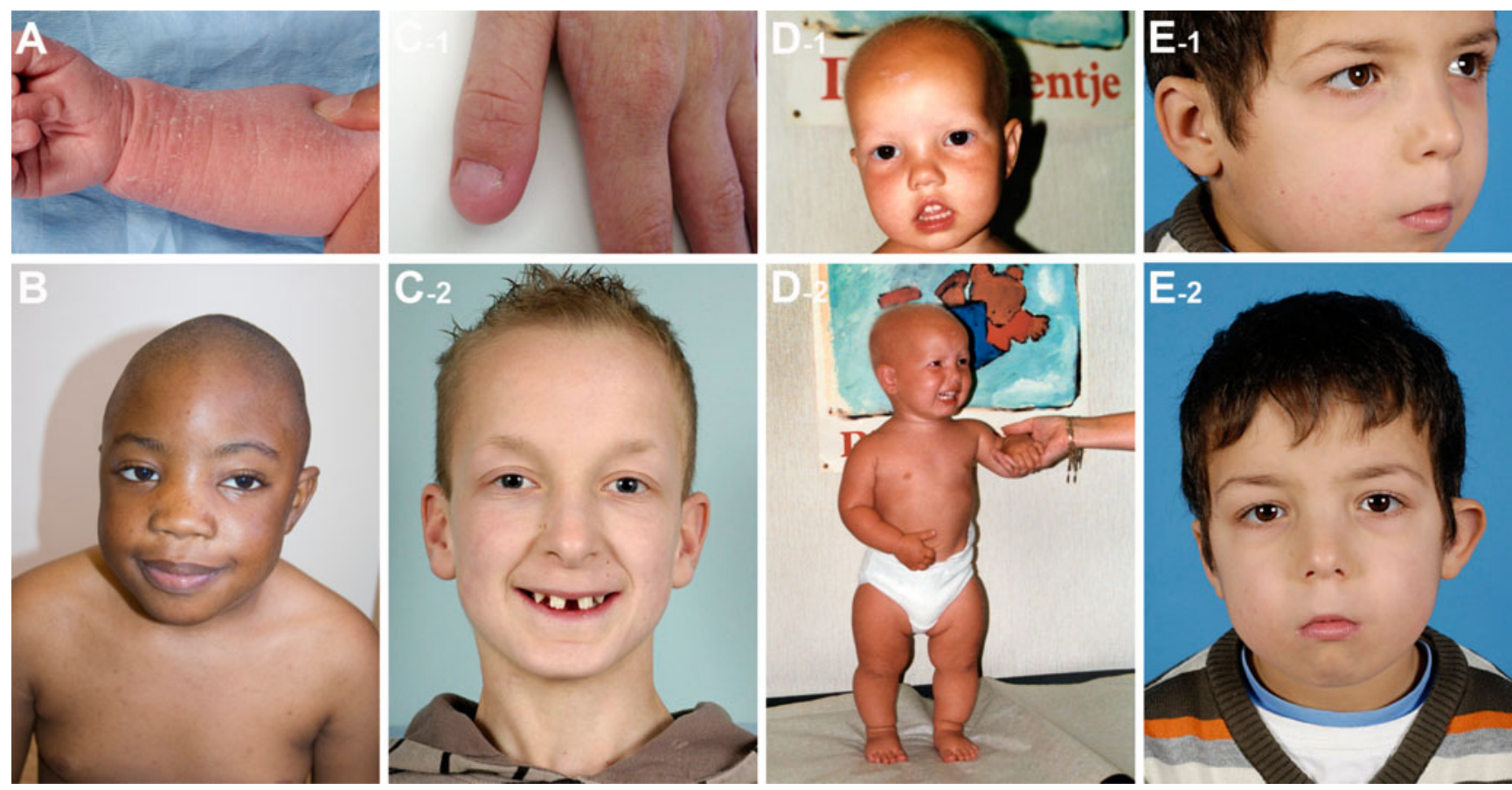

Fig. 2 Dysmorphic features in other syndromic PID. (a) WiskottAldrich syndrome: note the dry skin with eczema; (b) hyper-IgE syndrome: note the broad nasal bridge, wide fleshy nasal tip, and mild prognathism; (c-1, c-2) Hypo-/anhidrotic ectodermal dysplasia with immunodeficiency: note the high square forehead and ectodermal dysplasia with dry skin, nail dysplasia, and conical wide spaced teeth;

(d-1, d-2) Cartilage-hair hypoplasia: note the disproportional short stature associated with fine and sparse hair; $(\mathbf{e}-1, \mathbf{e}-2) 22$ q11.2 deletion syndrome: note the mild hypertelorism, downslanting of palpebral fissures, hooded eyelids, hypoplasia of the alae nasi, prominent nose with squared nasal root and narrow alar base, and small square low-set ears

with eczema and severe infections but are not accompanied by microthrombocytopenia.

Microthrombocytopenia is the most distinctive
feature of Wiskott-Aldrich syndrome, whereas the
classical triad including microthrombocytopenia,
recurrent infections and atopic eczema is present in
only one fourth of patients.

\section{Hyper-IgE syndrome}

The hyper-IgE syndrome (HIES) was first described in 1966 by Davis and Wedgwood, which named it the "Job syndrome", after the biblical figure Job who was covered with sore boils [13]. The classical description of HIES is a triad of: (a) recurrent staphylococcal skin abscesses without typical features of inflammation called "cold abscesses", (b) recurrent pneumonia with pneumatocele formation, and (c) highly elevated levels of serum IgE. More recently, the

genetic basis was unraveled showing genetic heterogeneity with both autosomal dominant (AD) and autosomal recessive (AR) forms of HIES. AD HIES is caused by dominant negative variants in the STAT3-gene (OMIM 147060) [34, 48]. AR HIES has been shown to be caused by mutations causing loss of tyrosine kinase 2 (TYK2) (OMIM 611521) or dedicator Of cytokinesis 8 (DOCK8) (OMIM 243700). Most reported cases of AR HIES were due to DOCK8 loss explaining 16 out of 20 families that were described [20], while TYK2 loss has been described only twice worldwide $[20,47,86]$.

AD HIES is characterized by typical dysmorphic features such as facial asymmetry, prominent forehead, deep-set eyes, broad nasal bridge, wide fleshy nasal tip, high-arched palate, and mild prognathism that become apparent in late puberty (Fig. 2b) [26]. Furthermore, patients may manifest skeletal abnormalities including failure or delay of shedding primary teeth, pathologic fractures, and scoliosis [26]. Patients may present with early-onset atopic dermatitislike eczema, which is resistant to treatment. Immunologically, AD HIES is characterized by high serum IgE levels, eosinophilia, chronic mucocutaneous candidiasis, and severe recurrent airway and ENT infections with Staphylococcus aureus, Streptococcus pneumoniae, and Haemophilus influen- 
zae, and occasionally, Aspergillus. Pneumatoceles develop in approximately $75 \%$ of patients.

Features such as dysmorphisms and skeletal problems are variably associated with AR HIES, while pneumatocele formation was infrequently seen in patients with DOCK8or TYK2-mutations [20]. Furthermore, patients may suffer from asthma, allergies, central nervous system symptoms, and autoimmune phenomena. In addition to the immunological features that are found in AD HIES, patients with AR HIES demonstrate unusual susceptibility to various viruses resulting in recurrent serious molluscum contagiosum and herpes simplex infections, while patients with TYK2-associated HIES also demonstrated increased susceptibility to mycobacteria $[20,47,90]$.

Importantly, AD HIES and a significant subgroup of AR HIES (DOCK8) have been associated with early-onset squamous-cell carcinoma and lymphoma in some patients.

Although it is clear that immune-defects underlie the HIES phenotype, no straightforward simple quantitative changes in $\mathrm{B}$ and $\mathrm{T}$ cell numbers and immunoglobulin levels have been described, besides high levels of $\operatorname{IgE}$ and eosinophilia to distinguish HIES from other diseases. However, in early childhood, normal IgE levels cannot definitely rule out HIES as these may increase at a later age as well. In older patients, IgE levels may become normal again [26].

HIES can be suspected from the typical clinical picture and diagnosis can be confirmed by mutational screening of STAT3, TYK2, or DOCK8. Clinical suspicion can be increased by following the NIH scoring system, which especially helps identifying patients with STAT3-associated HIES [27, 87]. Interestingly, a recent study showed that 25 patients with a clinical diagnoses of HIES (including patients with AD HIES and AR HIES), all had impaired $\mathrm{T}_{\mathrm{H}} 17$ responses, suggesting that this test may be used as a first confirmation of a clinical suspicion of HIES [1]. As such, it is now incorporated into the NIH scoring system [87]. Differential diagnosis with severe atopic dermatitis can be difficult in the first years of life, even more because high levels of serum IgE (up to $\sim 25.000 \mathrm{U} / \mathrm{ml}$ ) may be present. WAS, characterized by severe intractable eczema of neonatal onset, can be differentiated by testing for microthrombocytopenia.

Normal IgE levels cannot definitely rule out HIES.

One should include Hyper-IgE syndrome, but also

parasitic infections and atopic dermatitis in the

differential diagnosis of high IgE levels.
Hypo-/anhidrotic ectodermal dysplasia with immune-deficiency

Hypo-/anhidrotic ectodermal dysplasia with immunedeficiency (HED-ID; OMIM 300291) is characterized by diminished or absent sweat glands, thin and sparse hair, conical incisors, nail dysplasia, hypodontia, and immunodeficiency (Fig. 2c-1 and 2c-2). Most cases of HED-ID are caused by hypomorphic mutations in the $N E M O$-gene [nuclear factor $\mathrm{kB}(\mathrm{NF}-\mathrm{kB})$ essential modulator], which is located on the X-chromosome [14]. As the disease follows an X-linked recessive inheritance pattern, mostly males are affected, although affected females have been described. More severe mutations in NEMO result in incontinentia pigmenti, an ectodermal dysplasia without immunodeficiency that presents exclusively in females. Hypermorphic mutations in $I \kappa B \alpha$ causes an autosomal dominant type of HED-ID and has been reported twice $[11,35]$. HED-ID is one of the many different ectodermal dysplasias encompassing more than 200 conditions involving a combination of disorders of hair, nails, teeth, and sweat glands. Some children with HED-ID manifest a more severe phenotype with osteopetrosis and lymphedema (OL-EDA-ID; OMIM 300301).

From early childhood on, affected patients may suffer from unusually severe, life-threatening, and recurrent bacterial infections of the lower respiratory tract, skin, soft tissues, bones, digestive tract, leading to bronchiectasis, chronic lung disease, intractable diarrhea, and failure to thrive. The commonly implicated pathogens are S. pneumoniae, S. aureus, Pseudomonas, H. influenzae, and mycobacteria, but pathogens such as $P$. jiroveci and Candida (causing opportunistic infections) have been described as well [7, 31]. Also, increased susceptibility to HSV may predispose to HSV encephalitis [50]. Severity and spectrum of features may vary strongly. More recently, cases of HED-ID have been described with few ectodermal features but increased susceptibility to infections $[50,58]$.

Immunologically, it can be difficult to suspect HED-ID from routine immunological assessment as findings are generally non-specific. $\mathrm{T}$ and $\mathrm{B}$ cell numbers are mostly normal but can be increased (especially naïve CD4+ CD45RA $+T$ cells) $[31,35]$. In addition, immunoglobulin levels may vary. However, in a retrospective study, 24 out of 41 (59\%) of HED-ID patients had hypogammaglobulinemia. Some of the latter group also had increased IgM levels and thus demonstrated a phenotype reminiscent of hyper-IgM syndrome. Other possibly distinctive features were a specific polysaccharide antibody deficiency (in 13 out of 16 patients), a specific antibody response defect (in 18 out of 28 patients) and an elevated IgA level (in 13 out 35 patients) [31]. More specific in vitro tests evaluating $\mathrm{NF}-\mathrm{KB}$ activation after specific stimuli such as TNF $\alpha$ and anti-CD40 may prove useful in the future. 
Diagnosis is primarily based on the combination of clinical features, including infectious problems and ectodermal dysplasia, and can be confirmed by molecular genetic testing of $N E M O$ or $I \kappa B \alpha$. As the clinical picture may be highly variable from typical patients to patients without ectodermal dysplasia with recurrent pneumococcal infections, setting the right diagnosis can be very difficult. Differential diagnosis includes several ectodermal dysplasias (OMIM 612782 and 612783) [22], hyper-IgM syndrome, and milder forms of SCID.

\section{Cartilage-hair hypoplasia}

Cartilage-hair hypoplasia (CHH; OMIM 250250), also known as metaphyseal chrondodysplasia McKusick type, is a rare autosomal recessive short-limb dwarfism syndrome associated with fine and sparse hair, defective cellular immunity, and predisposition to several cancers (e.g., nonHodgkin's lymphoma and basal cell carcinoma; Fig. 2d-1 and 2d-2) [75]. The syndrome is caused by mutations in the $R M R P$-gene [62]. Incidence is higher in genetic isolates such as in Finland and in the old-order Amish communities in the USA [63]. The radiologic features include metaphyseal dysplasia with shortened tubular bones, bowed femora with rounded distal epiphyses, disproportionally long fibula, and cone-shaped epiphyses of the hand. Severity is variable, and radiographic changes are often inconspicuous in the first few years, although often, growth failure and sparse hair can be seen [36]. Other less frequent clinical features include defective erythropoiesis, bone marrow aplasia, and Hirschsprung disease [80, 85].

Defective immunity is a major feature in $\mathrm{CHH}$. An increased tendency to infections (mainly bacterial pneumonias) is present in $40-50 \%$, predominantly in the first 2 years of life [64]. Early studies described CHH patients who suffered from fatal complications of varicella [39]. In some, severe autoimmune features have been described including autoimmune hemolytic anemia and autoimmune enteropathy [5]. Morbidity and mortality are both directly the consequence of immune dysfunction [41].

In $\mathrm{CHH}$, usually, only cellular immunity is involved, but sporadically, both cellular and humoral immunity show defects. One third of the patients show lymphopenia, and over $80 \%$ show abnormal lymphocyte proliferation upon stimulation with mitogens. IgA and/or IgG subclass deficiency is present in more than one third of $\mathrm{CHH}$ patients [40].

In view of possible deficient immunity, it is recommended that all affected $\mathrm{CHH}$ patients are carefully monitored for signs of increased susceptibility to infections during the first 2 years of life. Several studies suggest that many individuals with $\mathrm{CHH}$ can safely receive live vaccines, although these should be avoided in CHH patients who clearly have SCID [64].

As metaphyseal abnormalities on radiographs may

be absent in infancy, Cartilage-Hair Hypoplasia

should be considered in all patients with a small

stature and unexplained lymphopenia.

\section{2q11.2 deletion syndrome/Shprintzen syndrome/ DiGeorge syndrome}

The 22q11.2 deletion syndrome (OMIM 192430), the most common human deletion syndrome, is characterized by a plethora of clinical features [65]. TBX1, one of the genes located in the deleted region, is considered to be the major gene involved. DiGeorge syndrome (historically referring to patients with heart, thymus, and parathyroid gland abnormalities) and Shprintzen syndrome/Velo-Cardio-Facial syndrome (characterized by cleft palate or velopharyngeal insufficiency, congenital heart malformations, and a typical facial Gestalt) not only share clinical features but also a common deletion. For this reason, "22q11 deletion syndrome" is the preferred nomenclature to describe these clinical entities associated with this deletion. Conotruncal heart malformations (50-80\%), such as tetralogy of Fallot or interruption of the aortic arch form the most common group of congenital malformations. The face is typically characterized by hooded eyelids, a bulbous nasal tip with hypoplastic alae nasi and small ears (Fig. 1i, j) [65]. Psychomotor development is often delayed, and an increased incidence of psychosis is reported [25].

Recurrent ENT infections are the most common immunological feature. A fraction of 22q11 patients also develop autoimmune diseases such as juvenile rheumatoid arthritis and hematologic autoimmune disease [12, 15]. Although infectious problems are mild to moderate in the majority of patients, an estimated $80 \%$ of 22 q. 11.2 deletion patients have low $\mathrm{T}$ cells. Remarkably, there is a slower decrease of $\mathrm{T}$ cells compared with age-related control individuals [43]. In addition to $\mathrm{T}$ cell abnormalities, IgA deficiency [71], impaired responses to vaccines, and frank hypogammaglobulinemia have been described. Subtle defects in the B cell compartment such as decreased proportions of memory B cells have also been reported [43]. Only $1 \%$ of patients lack $\mathrm{T}$ cells due to aplasia of the thymus, which has classically been described as DiGeorge syndrome. This specific subset of patients is at risk for serious infections and requires irradiated blood products to prevent graft versus host disease. 
Therefore, at diagnosis T cell characterization and evaluation of serum immunoglobulin levels is recommended.

The immune status should be checked in infants
with 22q11.2 deletion syndrome before
administering blood products, in order to determine
if irradiation of the blood is indicated.

\section{Down syndrome}

Down syndrome is the most common chromosomal disorder and is commonly caused by trisomy 21 . It is generally thought that changes in expression levels of multiple genes on chromosome 21 and secondary on other chromosomes are causative of the phenotype ("the gene dosage hypothesis"). Studies in patients with partial trisomy have pointed at certain regions on chromosome 21 for disorders such as leukemia and congenital heart disease, but have not yet shown linkage to a particular region with respect to increased susceptibility to infections [37]. More likely, subtle differences in expression of multiple genes are involved, affecting a variety of cell types thereby resulting in immune imbalance [60, 72].

Infections of especially the lower respiratory tract contribute significantly to morbidity and mortality in patients with Down syndrome [89]. Also, upper respiratory tract infections are more common than in children without trisomy 21 [33]. Specifically, it was recently shown that Down syndrome is an independent risk factor for severe lower respiratory tract infections with respiratory syncytial virus with an OR of 12,6 [4, 44]. To what extent an underlying immunological defect is causative remains a matter of discussion, as multiple other causes may influence infection rate as well (e.g., more frequent institutionalization, aspiration). Several differences in $\mathrm{B}, \mathrm{T}$, and NK cell numbers have been reported in children with Down syndrome as well as changes in immunoglobulin levels and granulocyte function, which have not been consistent and mostly cannot be interpreted simply as a cause of immunodeficiency $[8,9,38,45,61,77]$. As such, most findings in routine immunological screening, at the moment, do not contribute to identifying those children at risk for recurrent infections and do not provide a therapeutic value. An interesting exception to this was the recent observation that MBL deficiency increases susceptibility to respiratory tract infections in Down syndrome patients, which may be used to identify patients at risk for infectious disease such as RSV [51].
Down syndrome patients may be at increased risk

for recurrent infections, careful follow-up should

identify those patients in need of supportive

measures.

\section{Discussion}

In this report, we provided an overview of some of the most important syndromic immunodeficiencies. Key in identifying syndromic immunodeficiencies is the awareness that increased susceptibility to infections or immune dysregulation in a patient known to have other pathology may hint at an underlying genetic syndrome. Other organ systems frequently found to be involved are the ectodermal, skeletal, nervous, and gastrointestinal systems. Clinical features not directly associated with the immune defect may be prominent and be the first presentation. For this, Table 1 is providing a differential diagnosis on the basis of several key features. On the other hand, syndromic immunodeficiencies may present with serious infections as well, with extraimmune symptoms arising at a later time point.

Clinical presentation and coming to a diagnosis Microcephaly with recurrent infections may point at one of the several DNA repair or DNA maintenance disorders. Small stature and intrauterine growth retardation may be important clues to the correct diagnosis because disorders such as Cernunnos deficiency, Bloom syndrome, and Hoyeraal Hreidarsson syndrome frequently have proportional growth retardation, which is already present at birth. Severe difficulty to treat "eczema" and microthrombocytopenia in a male makes the diagnosis of WAS almost certain. Patients with chromosomal aberrations such as $22 \mathrm{q} 11$ deletion syndrome most likely present with other features such as facial dysmorphisms, cardiac defects, or velopharyngeal insufficiency because the immune-defect is mostly mild. Thorough examination of the mucocutaneous surface for atopic dermatitis, ectodermal dysplasia, candidiasis, hypopigmentation, or warts may be very helpful in delineating the specific syndrome.

Opportunistic infections with cryptococcal or invasive fungal infections, are rarely seen in most syndromic immunodeficiencies but may be present in WAS, ICF syndrome, Hoyeraal-Hreidarsson syndrome, HED-ID, HIES, and Cartilage-hair hypoplasia. In A-T and NBS, opportunistic infections have never been described. In Chediak-Higashi syndrome and Griscelli syndrome severe immune dysregulation such as hemophagocytic 
lymphohistiocytosis has been reported to occur more frequently.

An increased risk for malignancy has been reported in multiple syndromic immunodeficiencies. In DNA repair disorders like A-T, NBS, and Bloom syndrome there is a high risk for malignancy, and patients are mostly at risk for leukemias, lymphomas, and solid tumors later in life. Treatment may be difficult, because conventional radiation dosages are dangerous, radiomimetic drugs may have to be avoided and other cytostatics have to be used at reduced dosages. Therefore, patients need a specific therapeutic approach. Also in WAS, CHH, and HIES, there is an increased risk for malignancies (mainly lymphomas), which warrants careful follow-up irrespective of the immunological status and extending beyond pediatric age.

Early diagnosis is essential for adequate treatment and follow-up Because of the complex pathology in many of these syndromes, follow-up in a multidisciplinary team is warranted. In general, immunological surveillance is the same as in other primary immunodeficiencies (see the first paper in this educational series by de Vries et al.). Inactivated vaccines can be administered without problem, but care should be taken with administering live-attenuated vaccines. Patients at risk for opportunistic or other infections may be treated with prophylactic antimicrobial agents. For more severe humoral immunodeficiency, immunoglobulin substitution is indicated. As some of the immunodeficiency syndromes have a poor prognosis due to a severe course of the disease, conservative treatment with supporting measures may not be sufficient. For several diseases such as HED-ID, severe WAS, and CHH, bone marrow transplantation has been employed with great success $[5,10,17,57,59]$.

Bone marrow transplantation has improved prospects for many patients with a syndromic PID For WAS boys who received BMT from a matched healthy sibling or closely matched unrelated donor before the age of 5 years had a greater than $85 \%$ probability of being cured [57]. In a recent European collaborative survey, 16 patients with $\mathrm{CHH}$ and immunodeficiency underwent HSCT, mostly at a young age [5]. Overall survival was $62,5 \%$, and surviving patients had good reconstitution of the immune system with autoimmunity resolved post-transplantation. Analogous to other patient groups, the outcome with matched-related donors was significantly better than haploidentical bone marrow transplantation. In Cernunnos/XLF deficiency, Ligase IV deficiency, Hoyeraal-Hreidarsson syndrome, ICF syndrome, and NBS, successful bone marrow transplantation has been reported, but long-term studies are not yet available [2, 18, $21,28]$. One of the remaining hopes is that BMT may also decrease the risk for malignancy. As bone marrow transplantation can have severe side effects, the decision to transplant is strongly dependent on the type of disorder, long-term prognosis, severity in which the patient is affected, age of the patient, and availability of an adequate donor.

Genetic counseling is appropriate in all syndromic immunodeficiencies Early diagnosis can be very important as stringent follow-up may identify clinical problems at an earlier stage and may make treatment easier. As many syndromic immunodeficiencies may have an atypical presentation, it is advisable to involve clinical geneticists at an early stage. The clinical geneticist can also help in counseling the parents and helping them adapt to the situation. Moreover, it is appropriate to offer genetic counseling (including discussion of potential risks to offspring and reproductive options) to parents with a previous affected child or to young adults who are affected or at risk of being carriers. Obviously, the optimal timing for counseling on the recurrence risk, clarification of carrier status, and discussion of the availability of prenatal testing is before a new pregnancy is conceived.

Acknowledgments The authors would like to thank R. Koppenol and T. de Vries Lentsch for their excellent assistance with the photographic work, and Dr. A. Wagner, Dr. G. Driessen, Dr. A. Warris and the department of Orthodontics of the Erasmus MC Rotterdam for kindly providing photographs.

Conflict of interest All authors declare no conflict of interest.

Open Access This article is distributed under the terms of the Creative Commons Attribution Noncommercial License which permits any noncommercial use, distribution, and reproduction in any medium, provided the original author(s) and source are credited.

\section{References}

1. Al Khatib S, Keles S, Garcia-Lloret M et al (2009) Defects along the $\mathrm{T}(\mathrm{H}) 17$ differentiation pathway underlie genetically distinct forms of the hyper IgE syndrome. J Allergy Clin Immunol 124 (2):342-348, 348 e $341-345$

2. Albert MH, Gennery AR, Greil J et al (2010) Successful SCT for Nijmegen breakage syndrome. Bone Marrow Transplant 45 (4):622-626

3. Andreu N, Pujol-Moix N, Martinez-Lostao L et al (2003) WiskottAldrich syndrome in a female with skewed X-chromosome inactivation. Blood Cells Mol Dis 31(3):332-337

4. Bloemers BL, van Furth AM, Weijerman ME et al (2007) Down syndrome: a novel risk factor for respiratory syncytial virus bronchiolitis-a prospective birth-cohort study. Pediatrics 120(4): e1076-e1081

5. Bordon V, Gennery AR, Slatter MA et al (2010) Clinical and immunologic outcome of patients with cartilage hair hypoplasia after hematopoietic stem cell transplantation. Blood 116(1):2735

6. Buck D, Malivert L, de Chasseval R et al (2006) Cernunnos, a novel nonhomologous end-joining factor, is mutated in human immunodeficiency with microcephaly. Cell 124(2):287-299 
7. Carrol ED, Gennery AR, Flood TJ et al (2003) Anhidrotic ectodermal dysplasia and immunodeficiency: the role of NEMO. Arch Dis Child 88(4):340-341

8. Cetiner S, Demirhan O, Inal TC et al. (2010) Analysis of peripheral blood T-cell subsets, natural killer cells and serum levels of cytokines in children with Down syndrome. International journal of immunogenetics

9. Cocchi G, Mastrocola M, Capelli M et al (2007) Immunological patterns in young children with Down syndrome: is there a temporal trend? Acta Paediatr 96(10):1479-1482

10. Coman D, Herbert A, McGill J et al (2008) Unrelated cord blood transplantation in a girl with Hoyeraal-Hreidarsson syndrome. Bone Marrow Transplant 42(4):293-294

11. Courtois G, Smahi A, Reichenbach J et al (2003) A hypermorphic IkappaBalpha mutation is associated with autosomal dominant anhidrotic ectodermal dysplasia and T cell immunodeficiency. J Clin Investig 112(7):1108-1115

12. Davies K, Stiehm ER, Woo P et al (2001) Juvenile idiopathic polyarticular arthritis and IgA deficiency in the 22q11 deletion syndrome. J Rheumatol 28(10):2326-2334

13. Davis SD, Schaller J, Wedgwood RJ (1966) Job's Syndrome. Recurrent, "cold", staphylococcal abscesses. Lancet 1 (7445):1013-1015

14. Doffinger R, Smahi A, Bessia C et al (2001) X-linked anhidrotic ectodermal dysplasia with immunodeficiency is caused by impaired NF-kappaB signaling. Nat Genet 27(3):277-285

15. Duke SG, McGuirt WF Jr, Jewett T et al (2000) Velocardiofacial syndrome: incidence of immune cytopenias. Arch Otolaryngol Head Neck Surg 126(9):1141-1145

16. Dupuis-Girod S, Medioni J, Haddad E et al (2003) Autoimmunity in Wiskott-Aldrich syndrome: risk factors, clinical features, and outcome in a single-center cohort of 55 patients. Pediatrics 111(5 Pt 1):e622-e627

17. Dupuis-Girod S, Cancrini C, Le Deist F et al (2006) Successful allogeneic hemopoietic stem cell transplantation in a child who had anhidrotic ectodermal dysplasia with immunodeficiency. Pediatrics 118(1):e205-e211

18. Ehrlich M, Jackson K, Weemaes C (2006) Immunodeficiency, centromeric region instability, facial anomalies syndrome (ICF). Orphanet J Rare Dis 1:2

19. Ellis NA, Groden J, Ye TZ et al (1995) The Bloom's syndrome gene product is homologous to RecQ helicases. Cell 83(4):655-666

20. Engelhardt KR, McGhee S, Winkler S et al (2009) Large deletions and point mutations involving the dedicator of cytokinesis 8 (DOCK8) in the autosomal-recessive form of hyper-IgE syndrome. J Allergy Clin Immunol 124(6):1289-1302, e1284

21. Faraci M, Lanino E, Micalizzi C et al (2009) Unrelated hematopoietic stem cell transplantation for Cernunnos-XLF deficiency. Pediatr Transplant 13(6):785-789

22. Feske S, Picard C, Fischer A (2010) Immunodeficiency due to mutations in ORAI1 and STIM1. Clin immunol (Orlando Fla) 135 (2):169-182

23. Gennery AR, Slatter MA, Bredius RG et al (2007) Hematopoietic stem cell transplantation corrects the immunologic abnormalities associated with immunodeficiency-centromeric instability-facial dysmorphism syndrome. Pediatrics 120(5): e1341-e1344

24. German J (1993) Bloom syndrome: a mendelian prototype of somatic mutational disease. Medicine 72(6):393-406

25. Green T, Gothelf D, Glaser B et al (2009) Psychiatric disorders and intellectual functioning throughout development in velocardiofacial (22q11.2 deletion) syndrome. J Am Acad Child Adolesc Psychiatry 48(11):1060-1068

26. Grimbacher B, Holland SM, Gallin JI et al (1999) Hyper-IgE syndrome with recurrent infections-an autosomal dominant multisystem disorder. N Engl J Med 340(9):692-702
27. Grimbacher B, Schaffer AA, Holland SM et al (1999) Genetic linkage of hyper-IgE syndrome to chromosome 4. Am J Hum Genet 65(3):735-744

28. Gruhn B, Seidel J, Zintl F et al (2007) Successful bone marrow transplantation in a patient with DNA ligase IV deficiency and bone marrow failure. Orphanet J Rare Dis 2:5

29. Hagleitner MM, Lankester A, Maraschio P et al (2008) Clinical spectrum of immunodeficiency, centromeric instability and facial dysmorphism (ICF syndrome). J Med Genet 45(2):93-99

30. Hansen RS, Wijmenga C, Luo P et al (1999) The DNMT3B DNA methyltransferase gene is mutated in the ICF immunodeficiency syndrome. Proc Natl Acad Sci USA 96(25):14412-14417

31. Hanson EP, Monaco-Shawver L, Solt LA et al (2008) Hypomorphic nuclear factor-kappaB essential modulator mutation database and reconstitution system identifies phenotypic and immunologic diversity. J Allergy Clin Immunol 122 (6):1169-1177, e1116

32. Hiel J, Weemaes CM (2000) Nijmegen breakage syndrome. The International Nijmegen Breakage Syndrome Study Group. Arch Dis Child 82(5):400-406

33. Hilton JM, Fitzgerald DA, Cooper DM (1999) Respiratory morbidity of hospitalized children with Trisomy 21. J Paediatr Child Health 35(4):383-386

34. Holland SM, DeLeo FR, Elloumi HZ et al (2007) STAT3 mutations in the hyper-IgE syndrome. N Engl J Med 357 (16): $1608-1619$

35. Janssen R, van Wengen A, Hoeve MA et al (2004) The same IkappaBalpha mutation in two related individuals leads to completely different clinical syndromes. J Exp Med 200(5):559-568

36. Kavadas FD, Giliani S, Gu Y et al (2008) Variability of clinical and laboratory features among patients with ribonuclease mitochondrial RNA processing endoribonuclease gene mutations. J Allergy Clin Immunol 122(6):1178-1184

37. Korbel JO, Tirosh-Wagner T, Urban AE et al (2009) The genetic architecture of Down syndrome phenotypes revealed by highresolution analysis of human segmental trisomies. Proc Natl Acad Sci USA 106(29):12031-12036

38. Kusters MA, Verstegen RH, Gemen EF et al (2009) Intrinsic defect of the immune system in children with Down syndrome: a review. Clin Exp Immunol 156(2):189-193

39. Lux SE, Johnston RB Jr, August CS et al (1970) Chronic neutropenia and abnormal cellular immunity in cartilage-hair hypoplasia. N Engl J Med 282(5):231-236

40. Makitie O, Kaitila I, Savilahti E (2000) Deficiency of humoral immunity in cartilage-hair hypoplasia. J Pediatr 137(4):487-492

41. Makitie O, Pukkala E, Kaitila I (2001) Increased mortality in cartilage-hair hypoplasia. Arch Dis Child 84(1):65-67

42. Maraschio P, Zuffardi O, Dalla Fior T et al (1988) Immunodeficiency, centromeric heterochromatin instability of chromosomes 1, 9, and 16, and facial anomalies: the ICF syndrome. J Med Genet 25(3): 173-180

43. McLean-Tooke A, Barge D, Spickett GP et al (2008) Immunologic defects in 22q11.2 deletion syndrome. J Allergy Clin Immunol 122(2):362-367, 367

44. Medrano Lopez C, Garcia-Guereta Silva L, Lirio Casero J et al (2009) Respiratory infections, Down's syndrome and congenital heart disease: the CIVIC 21 study. Pediatr Barc 71(1):38-46

45. Mehta PD, Dalton AJ, Mehta SP et al (1993) Immunoglobulin G subclasses in older persons with Down syndrome. J Neurol Sci 117(1-2):186-191

46. Michalkiewicz J, Barth C, Chrzanowska K et al (2003) Abnormalities in the T and NK lymphocyte phenotype in patients with Nijmegen breakage syndrome. Clin Exp Immunol 134(3):482490

47. Minegishi Y, Saito M, Morio T et al (2006) Human tyrosine kinase 2 deficiency reveals its requisite roles in multiple cytokine 
signals involved in innate and acquired immunity. Immunity 25 (5):745-755

48. Minegishi Y, Saito M, Tsuchiya S et al (2007) Dominant-negative mutations in the DNA-binding domain of STAT3 cause hyper-IgE syndrome. Nature 448(7157):1058-1062

49. Ming JE, Stiehm ER (2008) Genetic syndromic immunodeficiencies with antibody defects. Immunol Allergy Clin North Am 28 (4):715-736, vii

50. Niehues T, Reichenbach J, Neubert J et al (2004) Nuclear factor kappaB essential modulator-deficient child with immunodeficiency yet without anhidrotic ectodermal dysplasia. J Allergy Clin Immunol 114(6):1456-1462

51. Nisihara RM, Utiyama SR, Oliveira NP et al (2010) Mannanbinding lectin deficiency increases the risk of recurrent infections in children with Down's syndrome. Hum Immunol 71(1):63-66

52. Noordzij JG, Wulffraat NM, Haraldsson A et al (2009) Ataxiatelangiectasia patients presenting with hyper-IgM syndrome. Arch Dis Child 94(6):448-449

53. Notarangelo LD, Parolini O, Porta F et al (1991) Analysis of Xchromosome inactivation and presumptive expression of the Wiskott-Aldrich syndrome (WAS) gene in hematopoietic cell lineages of a thrombocytopenic carrier female of WAS. Hum Genet 88(2):237-241

54. Notarangelo LD, Fischer A, Geha RS et al (2009) Primary immunodeficiencies: 2009 update. J Allergy Clin Immunol 124 (6): 1161-1178

55. Nowak-Wegrzyn A, Crawford TO, Winkelstein JA et al (2004) Immunodeficiency and infections in ataxia-telangiectasia. J Pediatr 144(4):505-511

56. O'Driscoll M, Cerosaletti KM, Girard PM et al (2001) DNA ligase IV mutations identified in patients exhibiting developmental delay and immunodeficiency. Mol Cell 8(6):1175- 1185

57. Ochs HD, Filipovich AH, Veys P et al (2009) Wiskott-Aldrich syndrome: diagnosis, clinical and laboratory manifestations, and treatment. Biol Blood Marrow Transplant 15(1 Suppl):84-90

58. Orange JS, Levy O, Brodeur SR et al (2004) Human nuclear factor kappa $\mathrm{B}$ essential modulator mutation can result in immunodeficiency without ectodermal dysplasia. J Allergy Clin Immunol 114(3):650-656

59. Permaul P, Narla A, Hornick JL et al (2009) Allogeneic hematopoietic stem cell transplantation for X-linked ectodermal dysplasia and immunodeficiency: case report and review of outcomes. Immunol Res 44(1-3):89-98

60. Prandini P, Deutsch S, Lyle R et al (2007) Natural geneexpression variation in Down syndrome modulates the outcome of gene-dosage imbalance. Am J Hum Genet 81(2):252-263

61. Ribeiro LM, Jacob CM, Pastorino AC et al (2003) Evaluation of factors associated with recurrent and/or severe infections in patients with Down's syndrome. J Pediatr 79(2):141-148

62. Ridanpaa M, van Eenennaam H, Pelin K et al (2001) Mutations in the RNA component of RNase MRP cause a pleiotropic human disease, cartilage-hair hypoplasia. Cell 104(2):195-203

63. Ridanpaa M, Jain P, McKusick VA et al (2003) The major mutation in the RMRP gene causing CHH among the Amish is the same as that found in most Finnish cases. Am J Med Genet 121C (1):81-83

64. Rider NL, Morton DH, Puffenberger E et al (2009) Immunologic and clinical features of 25 Amish patients with RMRP 70 A- $>$ G cartilage hair hypoplasia. Clin immunology Orlando Fla 131(1):119-128

65. Ryan AK, Goodship JA, Wilson DI et al (1997) Spectrum of clinical features associated with interstitial chromosome 22q11 deletions: a European collaborative study. J Med Genet 34 (10):798-804

66. Savitsky K, Bar-Shira A, Gilad S et al (1995) A single ataxia telangiectasia gene with a product similar to PI-3 kinase. Sci NY NY 268(5218):1749-1753
67. Schubert R, Reichenbach J, Zielen S (2002) Deficiencies in CD4+ and $\mathrm{CD} 8+\mathrm{T}$ cell subsets in ataxia telangiectasia. Clin Exp Immunol 129(1):125-132

68. Schuetz C, Barbi G, Barth TF et al (2007) ICF syndrome: high variability of the chromosomal phenotype and association with classical Hodgkin lymphoma. Am J Med Genet A 143A (17):2052-2057

69. Schurman SH, Candotti F (2003) Autoimmunity in WiskottAldrich syndrome. Curr Opin Rheumatol 15(4):446-453

70. Sedgwick RP, Boder E (1991) Ataxia telangiectasia. In: Vinken PJ, Bruyn SW, de Jong JMBV (eds) Handbook of Clinical neurology, Hereditary Neuropathies and Spinocerebellar Atrophies, vol 60. Elsevier, New York, pp 347-393

71. Smith CA, Driscoll DA, Emanuel BS et al (1998) Increased prevalence of immunoglobulin A deficiency in patients with the chromosome 22q11.2 deletion syndrome (DiGeorge syndrome/ velocardiofacial syndrome). Clin Diagn Lab Immunol 5(3):415-417

72. Sommer CA, Pavarino-Bertelli EC, Goloni-Bertollo EM et al (2008) Identification of dysregulated genes in lymphocytes from children with Down syndrome. Genome/National Research Council Canada $=$ Genome $/$ Conseil national de recherches. Canada 51(1):19-29

73. Staples ER, McDermott EM, Reiman A et al (2008) Immunodeficiency in ataxia telangiectasia is correlated strongly with the presence of two null mutations in the ataxia telangiectasia mutated gene. Clin Exp Immunol 153(2):214-220

74. Sullivan KE, Mullen CA, Blaese RM et al (1994) A multiinstitutional survey of the Wiskott-Aldrich syndrome. J Pediatr $125(6$ Pt 1):876-885

75. Taskinen M, Ranki A, Pukkala E et al (2008) Extended follow-up of the Finnish cartilage-hair hypoplasia cohort confirms high incidence of non-Hodgkin lymphoma and basal cell carcinoma. Am J Med Genet A 146A(18):2370-2375

76. Thrasher AJ (2009) New insights into the biology of WiskottAldrich syndrome (WAS). Hematology/the education program of the American Society of Hematology American Society of Hematology:132-138

77. Ugazio AG, Maccario R, Notarangelo LD et al (1990) Immunology of Down syndrome: a review. Am J Med Genet Suppl 7:204-212

78. van der Burg M, van Veelen LR, Verkaik NS et al (2006) A new type of radiosensitive T-B-NK+severe combined immunodeficiency caused by a LIG4 mutation. J Clin Investig 116 (1):137-145

79. van der Burg M, Pac M, Berkowska MA et al (2010) Loss of juxtaposition of RAG-induced immunoglobulin DNA ends is implicated in the precursor B-cell differentiation defect in NBS patients. Blood 115(23):4770-4777

80. van der Burgt I, Haraldsson A, Oosterwijk JC et al (1991) Cartilage hair hypoplasia, metaphyseal chondrodysplasia type McKusick: description of seven patients and review of the literature. Am J Med Genet 41(3):371-380

81. Varon R, Vissinga C, Platzer M et al (1998) Nibrin, a novel DNA double-strand break repair protein, is mutated in Nijmegen breakage syndrome. Cell 93(3):467-476

82. Verhagen MM, Abdo WF, Willemsen MA et al (2009) Clinical spectrum of ataxia-telangiectasia in adulthood. Neurology 73 (6):430-437

83. Weemaes CM, Hustinx TW, Scheres JM et al (1981) A new chromosomal instability disorder: the Nijmegen breakage syndrome. Acta Paediatr Scand 70(4):557-564

84. Weemaes CM, Bakkeren JA, Haraldsson A et al (1991) Immunological studies in Bloom's syndrome. A follow-up report. Ann Génét 34(3-4):201-205

85. Williams MS, Ettinger RS, Hermanns P et al (2005) The natural history of severe anemia in cartilage-hair hypoplasia. Am J Med Genet A 138(1):35-40 
86. Woellner C, Schaffer AA, Puck JM et al (2007) The hyper IgE syndrome and mutations in TYK2. Immunity 26(5):535, author reply 536

87. Woellner C, Gertz EM, Schaffer AA et al (2010) Mutations in STAT3 and diagnostic guidelines for hyper-IgE syndrome. J Allergy Clin Immunol 125(2):424-432, e428

88. Xu GL, Bestor TH, Bourc'his D et al (1999) Chromosome instability and immunodeficiency syndrome caused by muta- tions in a DNA methyltransferase gene. Nature 402(6758):187191

89. Yang Q, Rasmussen SA, Friedman JM (2002) Mortality associated with Down's syndrome in the USA from 1983 to 1997: a population-based study. Lancet 359(9311):1019-1025

90. Zhang Q, Davis JC, Lamborn IT et al (2009) Combined immunodeficiency associated with DOCK8 mutations. N Engl J Med 361(21):2046-2055 